\title{
KEMAHIRAN BERBICARA BAHASA ARAB MELALUI PENCIPTAAN LINGKUNGAN BAHASA
}

\author{
Baiq Tuhfatul Unsi \\ Institut Agama Islam Bani Fattah Jombang, Indonesia \\ E-mail: bubaiq@yahoo.co.id
}

\begin{abstract}
Abstaract
Conversational skills is one of the skills to be achieved in the teaching of modern languages including Arabic. Talking is the primary means to build mutual understanding and mutual communication by using language as a medium. One of the factors that influence and determine the success of the learning process is the environment, not to mention the language environment. Quality language environment is something very important to the success of someone who is learning a second language, in this case Arabic. Bi'ah Arabiyyah is an environment where every activity is done with colored or Arabic. This method is very helpful in learning a foreign language because the students will apply and practice the language they have learned with no feeling nervous or embarrassed. Forming ability to speak Arabic and then enhance these capabilities is not easy, as the native language and the Arabic language has a lot of difference in terms of both linguistic and nonlinguistic. Training is needed to support the ability to speak Arabic. The exercises can be performed with the maximum if the language has created a conducive environment.
\end{abstract}

Keywords: Speaking Skills, Arabic Language Environment 


\section{Pendahuluan}

Bahasa adalah kunci ilmu pengetahuan. Memegang kunci utama bahasa berarti memegang kunci jendela dunia. Sebab sejuta pengetahuan, seribu peradaban yang tercipta semuanya ada dan terbahasakan, bahkan sejarah tidak akan terwujud sejarah jika tidak ada bahasa. Bahasa adalah satu-satunya kunci membuka jalan pencerahan bagi masa depan manusia.

Tidak diragukan mempelajari bahasa Arab adalah mempelajari ilmu untuk sesuatu yang besar karena sumber pengetahuan banyak yang menggunakan bahasa Arab. Di Indonesia bahasa Arab tidak hanya dipelajari sebagai bahasa agama tetapi juga bahasa pengetahuan. Selain diajarkan dalam usaha melestarikan budaya lokal, bahasa Arab juga dipelajari untuk memahami dan menafsirkan ayat-ayat Al-Qur'an, hadits, dan teks-teks Arab.

Ada beberapa hal yang menjadi ciri khas bahasa Arab yang tidak ada pada bahasa lain, beberapa diantaranya adalah: Jumlah abjad sebanyak 28 huruf dengan makhorijul huruf (tempat keluarnya huruf) yang tidak ada pada bahasa lainnnya, adanya huruf "dhad" yang tidak ada pada bahasa lainnya, kata kerja gramatikal yang digunakan selalu berubah sesuai dengan subyek yang berhubungan dengan kata kerja tersebut, dan lainlain. Aspek-aspek yang menjadi nilai lebih bahasa Arab di atas dalam waktu yang sama akan mungkin menjadi kendala bagi pembelajarnya, dikarenakan taraf kerumitan yang mendorong munculnya kesulitankesulitan dalam proses belajar mengajar. ${ }^{1}$

Suatu sistem pembelajaran bahasa Arab yang ideal, selain mampu mengantarkan pembelajar menguasai cabang-cabang ilmu, juga mampu mengantarkan menguasai keterampilan bahasa. Pembelajaran bahasa Arab secara garis besar dapat diklasifikasikan menjadi dua sistem: ${ }^{2}$

1. Sistem yang berorientasi pada penguasaan bahasa sebagai ujaran langsung (percakapan)

2. Sistem pembelajaran bahasa Arab yang berorientasi pada gramatika (tata bahasa)

Sistem pembelajaran bahasa Arab yang pertama lebih efektif mengantarkan pembelajar menguasai bahasa Arab sebagai alat komunikasi apabila di dukung oleh lingkungan sosial yang menggunakan bahasa Arab sebagai alat komunikasi sehari-hari. Lingkungan sosial

\footnotetext{
${ }^{1}$ Umi Machmudah dan Abdul Wahab Rosyidi, Active Learning Dalam Pembelajaran Bahasa Arab (Malang: UIN Maliki Press, 2008), 7-8

${ }^{2}$ Najmuddin Abdul Rouf, Bahasa Arab Super Lengkap (Yogyakarta: Familia, 2010), 1-3
} 
menuntut setiap orang yang ada di dalamnya untuk selalu berkomunikasi dengan bahasa Arab secara aktif.

Pembelajaran bahasa dipengaruhi oleh beberapa faktor. Faktor utama yang berkaitan erat dengan pemrolehan bahasa asing antara lain :

1. Bahasa pembelajar adalah salah satu gejala yang banyak diamati oleh peneliti untuk melihat pemrolehan. Salah satu dari gejala pembelajar ini misalnya kesalahan ${ }^{3}$

2. Faktor luar pembelajaran misalnya adalah lingkungan dan interaksi

3. Faktor internal dari pembelajaran diantaranya adalah pengaruh dari bahasa pertama atau bahasa lain

4. Pembelajar sebagai individu. Setiap pembelajar tentu mempunyai perbedaan dengan pembelajar lain. Mereka mempunyai strategi yang berbeda.

Salah satu faktor yang sangat mempengaruhi dan menentukan keberhasilan proses pembelajaran adalah lingkungan, tak terkecuali lingkungan berbahasa. Keberadaan lingkungan berbahasa Arab menjadi sangat penting karena ia selalu hadir, melingkupi, dan memberi nuansa dalam konteks pembelajaran bahasa Arab itu sendiri. Jika lingkungan tempat pembelajaran bahasa Arab itu kondusif, niscaya proses pembelajaran juga berlangsung kondusif. ${ }^{4}$

Keberhasilan seseorang dalam mempelajari bahasa dapat optimal apabila lingkungan bahasa mendapat perhatian serius. Meskipun pengajaran dirancang dengan baik dan pemberian pengetahuan tata bahasa dilakukan secara intensif, belum tentu peserta didik terampil berbahasa kedua bila tidak tersedia data masukan yang berupa pemakaian bahasa yang baik dari bahasa sasaran tersebut. ${ }^{5}$

Dari uraian di atas dapat kita ketahui, pentingnya penciptaan lingkungan untuk mendukung proses pembelajaran bahasa Arab khususnya dalam kmahiran berbicara bahasa Arab. Karena dalam hal ini Dulay menerangkan bahwa kualitas lingkungan bahasa sangat penting bagi seorang pembelajar untuk dapat berhasil dalam mempelajari bahasa

\footnotetext{
3 Dengan mengetahui kesalahan yang dilakukan oleh pembelajar maka kita akan mengetahui seberapa kemampuannya dalam menguasai bahasa target yang tengah ia pelajari. Lihat Abdul Wahab Rosyidi, Media Pembelajaran Bahasa Arab (Malang: UIN Malang Press, 2009), 18

4 Muhbib Abdul Wahab, Epistimologi dan Metodologi Pembelajaran Bahasa Arab (Jakarta: UIN Jakarta Press, 2008), 291-292

${ }^{5}$ Iskandar Wassid dan Dadang Sunendar, Strategi Pembelajaran Bahasa, 107
} 
baru (bahasa kedua). ${ }^{6}$ Sejalan dengan hal ini Para penganjur pendekatan linguistik kontrastif berpendirian bahwa penguasaan suatu bahasa tidak lain dari pembentukan kebiasaan-kebiasaan. Oleh karena itu untuk dapat menguasai bahasa kedua jalan yang paling tepat adalah dengan latihan yang terus menerus, tanpa henti, sehingga pada suatu saat akan terbentuk kebiasaan-kebiasaan seperti yang telah terjadi ketika mempelajari bahasa pertama. ${ }^{7}$ Dan kebiasaan-kebiasaan ini dapat dilaksanakan melalui penciptaan lingkungan bahasa Arab.

\section{Kemahiran Berbicara Bahasa Arab}

a. Pengertian

Kemahiran berbicara bahasa Arab adalah keterampilan menyampaikan pesan secara lisan dengan menggunakan bahasa Arab sebagai medianya, dengan tidak mengabaikan kaidah penggunaan bahasa sehingga apa yang disampaikan dengan mudah dimengerti oleh lawan bicara atau penerima pesan.

Seseorang dianggap memiliki kemampuan berbicara selama ia mampu berkomunikasi dengan lawan bicarannya. Dalam konteks komunikasi pembicara berlaku sebagai pengirim (sender), sedangkan penerima (receiver), adalah penerima warta (message). Warta terbentuk oleh informasi yang disampaikan sender dan message merupakan obyek dari komunikasi. Feed back muncul setelah warta diterima, dan merupakan reaksi dari penerima pesan. Oleh karena itu proses pembelajaran akan menjadi mudah jika peserta didik terlibat aktif berkomunikasi. ${ }^{8}$

Penggunaan bahasa secara lisan dipengaruhi oleh berbagai faktor yang secara praktis bisa kita simak, yaitu pelafalan, intonasi pilihan kata, struktur kata dan kalimat, sistematika pembicaraan, isi pembicaraan, cara memulai dan mengakhiri pembicaraan, serta penampilan (performance). ${ }^{9}$

Dalam memulai latihan berbicara, terlebih dahulu didasari oleh kemampuan mendengarkan, kemampuan penguasaan kosakata dan keberanian mengungkapkan apa yang ada di dalam pikirannya. ${ }^{10}$

\footnotetext{
${ }^{6}$ Abdul Chaer, Psikososiolinguistik Kajian Teoritik (Jakarta: PT Rineka Cipta, 2009), 257258

7 Abdul Chaer dan Leoni Agustina, Sosiolinguitik Perkenalan Awal (Jakarta: PT Rineka Cipta, 2004), 219

${ }^{8}$ Iskandar Wassid dan Dadang Sunendar, Strategi Pembelajaran Bahasa, 240

${ }^{9}$ Saiful Mustofa, Strategi Pembelajaran Inovatif, 138

${ }^{10}$ Saiful Mustofa, Strategi Pembelajaran Inovatif, 137
} 
Dalam belajar bahasa asing ${ }^{11}$ harus memenuhi empat syarat, yaitu: metode yang serasi, medianya dan buku-buku yang lengkap, gurunya punya kapabilitas tinggi, dan muridnya pun perlu bersungguh-sungguh belajar serta cerdas. Tanpa keempat tersebut terpenuhi, orang akan bertahun-tahun bahkan belasan tahun belajar bahasa Asing. ${ }^{12}$

Beberapa petunjuk umum berkenaan dengan pembelajaran kalam, yaitu sebagaimana berikut: ${ }^{13}$

1. Belajar kalam yakni berlatih berbicara

2. Hendaknya siswa mengungkapkan tentang pengalaman mereka

3. Melatih memusatkan perhatian

4. Tidak memutus percakapan dan sering membenarkan

5. Bertahap

6. Kebermaknaan tema

b. Jenis- Jenis Kemahiran Berbicara Bahasa Arab

Adapun jenis-jenis kemahiran berbicara bahasa Arab menurut Abd. Wahab Rosyidi dan Mamlu'atun Nafisah antara lain: ${ }^{14}$

1. Muhadatsah (percakapan)

Mubadatsah yaitu menyajikan pelajaran bahasa Arab melalui percakapan, dalam percakapan itu dapat terjadi antara guru dengan murid dan antara murid dengan murid, sambil menambah dan terus memperkaya perbendaharaan kata (mufrodat). ${ }^{15}$

Pada dasarnya tujuan mubadatsah adalah untuk melatih peserta didik untuk dapat berbicara dengan fasih dan dapat memahami apa yang dikatakan oleh lawan bicara atau orang lain. ${ }^{16}$

Dengan demikian aspek kemampuan harus dimiliki agar bisa berdialog adalah: dapat mendengarkan ucapan secara baik, memahami setiap ungkapan yang ditangkap, fasih dalam melafalkan kata perkata dan mampu menyusun kalimat dengan baik sehingga dapat dipahami lawan bicaranya.

Target yang bisa dilihat dari pada pembelajaran mubadatsah adalah :

\footnotetext{
${ }^{11}$ Khususnya dalam hal ini bahasa Arab

12 Ahmad Izzan, Metodologi Pembelajaran Bahasa Arab (Bandung: Humaniora, 2009), 91

${ }^{13}$ M. Abdul Hamid dkk, Pembelajaran Bahasa Arab; Pendekatan, Metode, Strategi, Materi, dan Media (Yogyakarta: Sukses Offset, 2008), 43-44

14 Abdul Wahab Rosyidi dan Mamlu'atun Ni'mah, Memahami Konsep Dasar Pembelajaran Bahasa Arab, 91

15 Ahmad Izzan, Metodologi Pembelajaran Bahasa Arab, 116

16 Wa Muna, Metodologi Pembelajaran Bahasa Arab Teori Dan Aplikasi (Yogyakarta: Sukses Offset, 2011), 67
} 
- Mampu melafalkan bahasa Arab secara fasih

- Mempu mengungkapkan kejadian-kejadian yang disaksikan dengan menggunakan bahasa Arab secara benar

- Mampu memahami, menterjemahkan, dan mengkomunikasikan kembali percakapan orang lain

2. Ta'bir syafahi (Ungkapan secara lisan)

Ta'bir syafahi adalah latihan membuat karangan secara lisan bertujuan untuk mengambangkan kemampuan pelajar dalam mengutarakan pikiran dan perasaannya. Melalui latihan ini, penguasaan pelajar terhadap kosa kata, pemilihan kata-kata yang tepat, tata-kalimat, dan tata bunyi seperti nada, irama, dan alunan suara. ${ }^{17}$

Adapun pokok dari ta'bir syafabi yang harus diperhatikan berikut pembelajarannya adalah: cerita, debat, pidato, seminar, dongeng, proses pembelajaran, menyampaikan pendapat, mengajukan pertanyaan, ungkapan maaf, terima kasih, permintaan, penyambutan, perpisahan, dll. ${ }^{18}$

Selaras dengan hal ini Aziz dan Al-Wasilah menyebutkan wujud dari maharah al-kalam diantaranya:

1. Mahir bercakap-cakap dan berkomunikasi dengan bahasa Arab secara Fasih dan benar, baik qawaid, ushlub, dan makhrojnya

2. Mahir berpidato, bercerita, berdiskusi, menterjemah, dan mengungkapkan pendapat dengan bahasa Arab

\section{Lingkungan Bahasa}

\section{a. Lingkungan Sebagai Sub Sistem Pembelajaran}

Salah satu faktor yang sangat mempengaruhi dan menentukan keberhasilan proses pembelajaran adalah lingkungan (environment, bi'ab), tak terkecuali lingkungan bahasa. Lingkungan adalah segala sesuatu yang ada di dalam sekitar yang memiliki makna dan pengaruh tertentu pada individu. ${ }^{19}$

Sedemikian pentingnya lingkungan pembelajaran itu, sehingga Nabi Muhammad saw. mengilustrasikan bahwa lingkungan keluarga itu dapat merubah keyakinan dan agama seorang anak yang

\footnotetext{
17 Ahmad Fuad Effendi, Metodologi Pengajaran Bahasa Arab, 146

نور هادى, الموجه لتعليم المهارة اللغهوية لغير النا طقين بها, (مالانق: مطبعة جا معة مولانا مالك ابراهيم 18

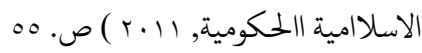

${ }^{19}$ Oemar Hamalik, Proses Belajar Mengajar (Jakarta: PT Bumi Aksara, 2009), 195
} 
dibesarkan dalam keluarga. Sabda Nabi saw.: "Setiap anak dilabirkan dalam keadaan fitrah. Kedua orang tuanyalah (ingkungan keluarga) yang kemudian menjadikan anak itu beragama Yabudi, Nashrani, atau Majusi....."(HR Muslim) $)^{20}$

Belajar bahasa yang baik adalah melalui praktek langsung. Karena bahasa merupakan alat komunikasi antar sesama manusia, maka pembelajaran yang tepat adalah melalui suatu lingkungan di mana di dalam lingkungan tersebut terdapat sistem yang mengatur pembiasaan bahasa Arab sehari-hari.

Lingkungan cukup mendukung atau menghambat proses penguasaan bahasa Arab. Apabila kita belajar bahasa arab dan berada di lingkungan yang berbahasa Arab, maka keadaan ini akan menjadi faktor pendukung percepatan pemahaman kita terhadap bahasa Arab yang sedang kita pelajari, dan sebaliknya. Karena itu lingkungan pendidikan yang berbahasa Arab diyakini memainkan peran penting dalam menunjang efektivitas pembelajaran bahasa Arab di lembaga pendidikan. ${ }^{21}$

b. Konsep Lingkungan Babasa

Pengertian lingkungan bahasa seperti yang dikemukakan oleh Hedei Dulay ${ }^{22}$ adalah segala hal yang didengar dan dilihat oleh pembelajar terkait dengan bahasa kedua yang sedang dipelajari. Yang tergolong lingkungan bahasa adalah situasi di rumah ketika nonton televisi, percakapan dengan kawan-kawan, dalam proses belajar mengajar di kelas, dan sebagainya.

Kualitas lingkungan bahasa amat penting dalam mencapai keberhasilan pembelajaran bahasa baru. Oleh sebab itu lingkungan bahasa yang baik adalah lingkungan yang dapat memberikan kesempatan seluas-luasnya bagi pembelajar untuk mendapatkan pajanan terhadap bahasa baru yang dipelajarinya. 23

Krashen $^{24}$ membagi lingkungan pembelajaran bahasa menjadi dua, lingkungan formal dan informal. Lingkungan formal,mencakup

${ }^{20}$ Muhbib Abdul Wahab, Epistimologi dan Metodologi Pembelajaran Bahasa Arab, 292

${ }^{21}$ Wa Muna, Metodologi Pembelajaran Bahasa Arab Teori Dan Aplikasi (Yogyakarta: Sukses Offset. 2011), 60

22 حليىى زهدى .البيئة اللغوية تكوينها ودورها فى اكتساب العربية , (Malang: UIN Malang Press, 2009), 38-39

23 Idham Kholid, Penelitian mandiri tentang pengarub lingkungan bahasa terhadap hasil pembelajaran bahasa Inggris pada MAN Model Bandar Lampung (2006) diterbitkan online, 910

${ }^{24}$ Ahmad Fuad Efendy, Metodologi Pengajaran Bahasa Arab, 165-166 
berbagai aspek pendidikan formal dan non formal, dan sebagian besar berada di dalam kelas atau laboratorium. Apakah lingkungan formal ini memberikan masukan kepada pembelajar berupa sistem bahasa (pengetahuan unsur-unsur bahasa) atau wacana bahasa (keterampilan berbahasa), tergantung kepada tipe pembelajaran atau metode yang digunakan oleh pengajar. Namun terdapat kecenderungan bahwa lingkungan formal memberikan lebih banyak sistem bahasa dari pada wacana bahasa. Lingkungan informal memberikan pajanan komunikasi yang alamiyah, dan sebagian besar berada di luar kelas. Oleh karena itu lingkungan informal ini memberikan lebih banyak wacana bahasa dapripada sistem bahasa.

Sejalan dengan hal ini Ellis ${ }^{25}$ menyebutkan adanya dua tipe pembelajaran bahasa yaitu: 1. tipe naturalistic, bersifat alamiah, tanpa guru, dan tanpa kesengajaan. Pembelajaran berlangsung di dalam lingkungan kehidupan masyarakat 2. tipe formal, berlangsung di dalam kelas dengan guru, materi, dan alat bantu belajar yang sudah dipersiapkan.

Krashen juga menyatakan bahwa untuk menguasai bahasa kedua pembelajar dapat menggunakan dua cara yakni melalui proses pembelajaran dan melalui proses pemerolehan. Pembelajaran merupakan proses yang disadari dan bertitik berat pada perhatian pembelajar pada bentuk bahasa atau struktur. Sedangkan pemerolehan merupakan proses yang serupa pada saat menerima bahasa pertama. Pemerolehan berlangsung sejalan dengan aktivitas yang tidak disadari oleh pembelajar. Dalam proses ini lazimnya lebih menekankan pada makna atau pesan, berlangsung secara alami,tanpa pengajaran formal.

Uraian di atas memperjelas bahwa lingkungan formal sangat berkaitan dengan pembelajaran. Lingkungan informal berkaitan dengan proses pemerolehan. Dalam komunikasi situasi formal frekuensinya relatif lebih sedikit dibandingkan dengan situasi informal. Hal ini menjadikan lingkungan informal lebih berperan daripada lingkungan formal.

25 Abdul Chaer, Psikososiolinguistike Kajian Teoritik, 243. Maka dalam hal ini juga, lingkungan bahasa menurut Dulay, Burt, dan Kreshen bersifat formal dan juga bisa bersifat alamiyah. Jika pajanan kata yang diterima pembelajar berupa bentuk (form) bahasa, lingkungan bahasa bersifat formal; ketika pajanan yang diterima pembelajar lebih difokuskan pada isi komunikasi lingkungan bahasa berbifat alamiah (natural). Lihat Idham Kholid, Penelitian mandiri tentang pengarub lingkungan bahasa terhadap hasil pembelajaran bahasa Inggris pada MAN Model Bandar Lampung, 10 
Dulay $^{26}$ menyatakan terdapat empat hal dari lingkungan bahasa yang berpengaruh dalam pemerolehan bahasa kedua, yakni, (1) sifat alami bahasa sasaran, (2) cara pembelajar dalam berkomunikasi, (3) adanya acuan yang konkret, dan (4) model bahasa sasaran.

1. Sifat alami bahasa sasaran

Kealamian bahasa yang di dengar diyakini dapat meningkatkan perkembangan keterampilan komunikasi bahasa kedua. Survey yang dilakukan carrol, Upsun, dan Mason $^{27}$ terhadap mahasiswa jurusan bahasa asing di Amerika Serikat yang dikutip oleh Dulay, Mariana Burt, dan Stephen Kreshen adalah salah satu studi pertama yang memperlihatkan kelebihan lingkungan bahasa alamiah dibandingkan dengan lingkungan bahasa formal dalam pemerolehan bahasa kedua. Mahasiswa jurusan bahasa asing di Amerika Serikat yang mengikuti kuliah tambahan bahasa Inggris dan yang tidak mengikuti kuliah tambahan. Ternyata pada akhir semseter, kemampuan berbahasa Inggris kedua kelompok itu hampir sama. ${ }^{28}$

2. Cara pembelajar dalam berkomunikasi

Dulay, Burt dan Krehen ${ }^{29}$ mengemukakan tiga tipe komunikasi dimana pembelajar berpartisipasi: a). satu arah( one way) b). dua arah terbatas (resticred two-way) c). dua arah penuh (full two-way)

Dalam komunikasi satu arah, pembelajar hanya membaca atau mendengar bahasa kedua, tetapi pembelajar tidak dapat merespon. Dalam komunikasi dua arah terbatas pembelajar akan mendengar bahasa kedua, kemudian memberikan respon secara nonverbal atau tidak menggunakan bahasa sasaran, seperti mengangguk. Sedangkan dalam komunikasi dua arah penuh pembelajar berbicara dalam bahasa target, berlaku sebagai penerima dan pengirim pesanpesan verbal.

3. Adanya acuan konkret

Adanya acuan bahasa yang konkret juga harus diperhatikan. Oleh karena itu, peristiwa yang diangkat sebagai bahan harus merupakan peristiwa atau hal yang dapat dilihat, didengar atau dirasakan secara langsung oleh pembelajar ketika percakapan sedang berlangsung. Komunikasi yang demikian dapat menjamin

\footnotetext{
${ }^{26}$ Abdul Chaer, Psikososiolinguistik Kajian Teoritik, 243

27 Abdul Chaer, Psikososiolinguistik Kajian Teoritik, 15

28 Ahmad Fuad Efendy, Metodologi Pengajaran Bahasa Arab, 165

29 Idham Kholid, Penelitian mandiri tentang pengaruh lingkungan bahasa terbadap hasil pembelajaran bahasa Inggris pada MAN Model Bandar Lampung, 18-19
} 
pembelajar dapat memahami banyak hal tentang apa yang dikatakannya dalam bahasa kedua. Dengan demikian dapat memicu perkembangan dan pemerolehan struktur dan kosakata bahasa sasaran.

4. Model bahasa sasaran

Dalam mempelajari bahasa kedua, pembelajar selalu memilih model yang mampu menghasilkan ujaran yang baik. Model bahasa kedua ini dapat dipilih sendiri oleh peserta didik dari lingkungan bahasanya. Model bahasa tersebut bisa kawan sepermainan, orang tua sendiri, pengajar/guru, buku-buku dan Koran, penyiar radio atau televisi dan sebagainya yang bisa ditemui.

Tentang lingkungan orang tua tampaknya hanya menjadi model dalam pemerolehan bahasa pertama. Dalam pembelajaran bahasa kedua, tampaknya tidak berperan apa-apa, kecuali kalau orang tua itu menempatkan diri sebagai pengajar dalam lingkungan formal.

Mengenai bahasa guru, menurut Krashen, mirip dengan bahasa pengasuh. Para guru cenderung menggunakan struktur kalimat yang pendek atau sederhana ketika berkomunikasi dengan pembelajar. Bahasa guru pada umumnya memiliki ciri penyesuaian secara formal pada seluruh tataran kebahasaan. Gaies melihat bahwa ujaran guru menampakkan penyederhanaan aturan sintaktik ketika ia berbicara di tengah-tengah siswanya. Henzl bahkan melihat bahwa bahasa guru pun seringkali disesuaikan dengan tataran kecakapan murid yang diajak berbicara. Dan Dulay berpendapat bahasa guru memang banyak mempengaruhi atau menjadi model bahasa siswa, tetapi pengaruhnya tidak sekuat pengaruh bahasa teman sebaya. ${ }^{30}$

Teman sebaya tampaknya memiliki pengaruh lebih besar dari pada orang tua atau guru terhadap pembelajar bahasa kedua. Penelitian ini dilakukan oleh Milon pada tahun 1957 menghasilkan simpulan bahwa seorang anak Jepang berusia tujuh tahun yang berimigrasi ke Hawai lebih memahami bahasa Inggris dialek yang dipelajari dari rekan sebayanya dari pada bahasa Inggris standart yang diajarkan oleh pengajarnya. Namun pada tahun berikutnya dia berpindah pada lingkungan kelas yang lebih tinggi, dengan cepat ia mampu memakai bahasa Inggris baku seperti yang dipakai oleh teman-teman barunya. ${ }^{31}$ Oleh karena itu, menurut Dulay, yang

${ }^{30}$ Idham Kholid, Penelitian Mandiri, 18-19

${ }^{31}$ Iskandar Wassid dan Dadang Sunendar, Strategi Pembelajaran Bahasa, 109 
sangat penting dalam pembelajaran bahasa kedua adalah menyediakan model teman sebaya dalam bahasa kedua yang sedang dipelajari. ${ }^{32}$

Selain kecenderungan umum lebih menyukai teman sebaya dibanding orang dewasa sebagai model bahasa, beberapa anak telah diamati memiliki kecenderungan terhadap dialek atau bahasa yang digunakan oleh anggota dari kelompok etniknya sendiri. Suatu penelitian yang dikutip Dulay, Burt, dan Krashen mengemukakan anak-anak Maori lebih suka belajar dialek bahasa Inggris mereka sendiri dibandingkan dengan bahasa Selandia Baru yang digunakan oleh anak-anak lain.

kecenderungan terhadap teman sebaya dibandingkan orang dewasa sebagai penutur model dan kecenderungan terhadap kelompok sosial yang lebih disukai dibanding dengan kelompok lain, secara signifikan berpengaruh terhadap kualitas bahasa yang dihasilkan. Oleh karena itu perbedaan karakteristik pembicaraan pembelajar yang dihasilkan dari pilihan model bukan disebabkan karena kesulitan belajar tetapi karena keanggotaan kelompok sosial yang disukai.

\section{c. Jenis Lingkungan Bahasa}

Uraian sebelumnya telah menjelaskan bahwa lingkungan bahasa terbagi menjadi dua yaitu lingkungan bahasa formal dan informal. Disini akan menjelaskan tentang lingkungan bahasa formal dan informal lebih gamblang lagi.

1. Lingkungan Bahasa Formal

Dulay dan Ellis ${ }^{33}$ menerangkan lingkungan formal34 adalah salah satu lingkungan dalam belajar bahasa yang menfokuskan pada penguasaan kaidah-kaidah bahasa yang sedang dipelajari secara sadar.

Sebenarnya lingkungan formal bahasa bukanlah terbatas pada kelas karena yang penting dalam lingkungan formal ini para pembelajar dapat secara sadar mengetahui kaidah-kaidah bahasa kedua yang dipelajari baik dari guru di dalam kelas, dari buku-buku, maupun dari orang lain di luar kelas. Yang penting lingkungan

\footnotetext{
32 Abdul Chaer, Psikososiolinguistik Kajian Teoritik, 260

33 حليىى زهدى .البيئة اللغوية تكوينها ودورها فى اكتساب العربية, (Malang: UIN Malang Press, 2009), 41

${ }^{34}$ Istilah lain dari lingkungan formal adalah lingkungan kelas
} 
tersebut menekankan pada penguasaan kaidah bahasa pada pembelajaran secara sadar. ${ }^{35}$

Sehubungan dengan ini krashen ${ }^{36}$ menyatakan bahwa lingkungan bahasa formal memiliki ciri : ${ }^{37}$

a. Bersifat artificial ( buatan, tidak alami)

b. Di dalamnya pembelajar diarahkan untuk melakukan aktivitas bahasa yang menampilkan kaidah-kaidah bahasa yang telah dipelajarinya, dan diberikannya balikan oleh guru dalam bentuk koreksi terhadap kesalahan yang dilakukan oleh pembelajar

c. Merupakan bagian dari keseluruhan pengajaran bahasa di sekolah atau di kelas

Lingkungan kelas sebagai salah satu lingkungan belajar bahasa disadari benar mempunyai sumbangan tertentu terhadap pemerolehan bahasa kedua, yaitu antara lain, membuat peserta didik lebih dapat bervariasi dalam menggunakan bahasanya secara lebih akurat dilihat dari kebenaran kaidahnya, dan penyajian kaidah tata bahasa lebih memuaskan keinginan peserta didik dewasa yang tertarik pada penguasaan kaidah atau aturan bahasa yang dipelajarinya.

2. Lingkungan Bahasa Informal

Lingkungan informal ${ }^{38}$ adalah segala hal yang didengar dan diamati oleh peserta didik sehubungan dengan bahasa kedua yang sedang dipelajarinya. ${ }^{39}$ lingkungan informal bersifat alami atau natural, tidak dibuat-buat. Yang termasuk lingkungan informal ini antara lain bahasa yang digunakan kawan-kawan sebaya, bahasa pengasuh atau orang tua, bahasa yang digunakan anggota kelompok etnis belajar, yang digunakan media massa, bahasa para guru, baik di kelas maupun luar kelas. ${ }^{40}$

Secara umum lingkungan ini sangat berpengaruh terhadap hasil belajar bahasa kedua para pembelajar. ${ }^{41}$ Lingkungan bahasa

35 Lingkungan kelas karena sifatnya yang sengaja diciptakan, memiliki karakteristik khusus, yaitu terprogram. Pusat perhatiannya pada penguasaan perangkat kaidah. Lihat Iskandar Wassid dan Dadang Sunendar, Strategi Pembelajaran Bahasa, 106

\footnotetext{
41-42 ,حليمى زهدى .البيئة اللغوية تكوينها ودورها في اكتساب العربية. 36

${ }^{37}$ Iskandar Wassid dan Dadang Sunendar, Strategi Pembelajaran Bahasa, 104

38 Istilah lain dari lingkungan informal adalah lingkungan alami atau lingkungan di luar kelas

${ }^{39}$ Iskandar Wassid dan Dadang Sunendar, Strategi Pembelajaran Bahasa, 106-107

40 Abdul Chaer, Psikososiolinguistik Kajian Teoritik, 260

${ }^{41}$ Abdul Chaer, Psikososiolinguistik Kajian Teoritik, 260
} 
informal (alamiah), baik di lingkungan asing (foreigh environtment) maupun lingkungan sendiri (bost environtment) diyakini dapat meningkatkan perkembangan keterampilan komunikasi bahasa kedua. $^{42}$

Lingkungan informal adalah lingkungan berbahasa yang sebenarnya. Sifat khas yang melekat pada lingkungan informal sebagai bentuk yang lain dari lingkungan bahasa yang umunya hadir bentuk masyarakat bahasa adalah sifatnya yang alami. Istilah lingkungan informal dalam konteks ini adalah hadirnya sebuah lingkungan berbahasa pada bahasa yang dipelajari, baik dalam bentuk penutur asli bahasa tersebut maupun masyarakat penutur yang sengaja diciptakan dalam pengajaran bahasa. ${ }^{43}$

Sifat khas lingkungan informal yang berpengaruh terhadap kecenderungan belajar dan kualitas hasil belajarnya dipengaruhi oleh empat faktor ${ }^{44}$ antara lain:

a. Sifat kealamiahan bahasa sasaran

b. Cara peserta didik dalam berkomunikasi dalam bahasa kedua

c. Ketersediaan model yang bisa ditiru untuk berbahasa

d. Adanya lingkungan berbahasa yang bisa mendukung komunikasi (ada banyak teman atau penutur yang memang sudah menguasai bahasa kedua, misalnya)

Dalam lingkungan bahasa yang bersifat alami titik berat komunikasi adalah isi pesan, bukan bentuk linguistiknya atau tata bahasa. Belajar bahasa secara alami akan memperlihatkan hasil kemampuan berbahasa yang lebih baik daripada melalui lingkungan formal yang lebih menitikberatkan pada pemerolehan bahasa secara sadar tentang aturan-aturan bahasa ataupun pemakaian bentuk formal linguistik.

Dalam lingkungan informal ini hendaknya peristiwa komunikasi harus benar-benar nyata, yang berkenaan dengan kepentingan sehari-hari. Misalnya percakapan tentang kebutuhan sehari-hari, rekreasi, kebutuhan sekolah dan belajar, keinginan menonton, dan sebagainya. Sifat dialog atau percakapan itu harus sekarang dan di sini. Semuanya harus dapat didengar, dilihat, atau dirasakan. Masukan-masukan yang demikianlah yang akan membawa kemajuan belajar itu.

42 Idham Kholid, Penelitian Mandiri, 11

43 Iskandar Wassid dan Dadang Sunendar, Strategi Pembelajaran Bahasa, 106

${ }^{44}$ Iskandar Wassid dan Dadang Sunendar, Strategi Pembelajaran Bahasa, 108 
Dari uraian di atas dapat dilihat secara jelas bahwa lingkungan di luar kelas mampu menjadi data masukan yang baik bagi peserta didik. Data masukan ini bila mengalami pengendapan akan menjadi pengetahuan linguistik yang berguna kelak sebagai alat komunikasi dalam dua bahasa dan sebagai alat untuk monitor. Lingkungan informal yang terpahami merupakan lingkungan bahasa yang baik bagi peserta didik.

\section{d. Prinsip-Prinsip Penciptaan Lingkungan Bahasa Arab}

Sebelum membahas penciptaan lingkungan bahasa Arab, terlebih dahulu akan dikemukakan tentang prasyarat penciptaan lingkungan bahasa. Untuk menciptakan lingkungan bahasa Arab ada beberapa prasyarat yang harus dipenuhi ${ }^{45}$ antara lain:

- Adanya sikap positif kepada bahasa Arab dan komitmen yang kuat untuk memajukan pengajaran bahasa Arab dari pihak-pihak yang terkait

- Adanya beberapa figur di lingkungan lembaga pendidikan yang mampu berkomunikasi dengan bahasa Arab, jika tidak dimungkinkan adanya penutur asli yang berperan sebagai penggerak sekaligus tim kreatif untuk menciptakan lingkungan bahasa Arab

- Tersedianya alokasi dana yang memadai, untuk mengadakan sarana dan prasarana yang diperlukan untuk untuk menciptakan lingkungan bahasa Arab

Dalam hal ini Muhbib ${ }^{46}$ menambahkan, yaitu adanya aturan main atau pedoman mengenai format dan model pengembangan lingkungan bahasa yang dikehendaki. Aturan main ini menjadi sangat penting untuk mengikat komitmen dan menyatukan visi dan tekad bersama untuk mengembangkan lingkungan berbahasa Arab. Jika dipandang perlu, dalam peraturan itu juga dibentuk semacam mabkamah al-lughoh yang berfungsi sebagai pemantau, pengawas kedisiplinan, berbahasa Arab, sekaligus pemutus dan pengeksekusi hukuman-hukuman tertentu bagi pelanggar kesepakatan bersama.

Adapun prinsip-prinsip menciptakan lingkungan berbahasa Arab yang perlu dijadikan landasan pengembangan sistem pembelajaran bahasa $\mathrm{Arab}^{47}$ adalah sebagai berikut :

\footnotetext{
45 Ahmad Fuad Efendy, Metodologi Pengajaran Bahasa Arab, 167

${ }^{46}$ Muhbib Abdul Wahab, Epistimologi dan Metodologi Pembelajaran Babasa Arab, 299

${ }^{47}$ Muhbib Abdul Wahab, Epistimologi dan Metodologi Pembelajaran Bahasa Arab, 301-302.
} 
Pertama, prinsip keterpaduan dengan visi, misi, dan orientasi pembelajaran bahasa Arab. Penciptaan lingkungan berbahasa Arab harus diletakkan dalam kerangka mendukung pencapaian tujuan pembelajaran bahasa Arab dan pemenuhan suasana yang kondusif bagi pemberdayaguanaan bahasa Arab secara aktif.

Kedua, prinsip skala prioritas dan gradasi program. Implementasi penciptaan lingkungan berbahasa Arab harus dilakukan secara bertahap dengan memperhatikan skala prioritas tertentu.

Ketiga, kebersamaan dan partisipasi aktif semua pihak. Secara psikologis, lingkungan pergaulan dalam berbahasa berpengaruh cukup signifikan dalam pembentukan kesadaran berbahasa asing.

Keempat, prinsip konsistensi dan keberlanjutan. Yang paling sulit dalam menciptakan lingkungan berbahasa adalah sikap konsistensi (istiqomah) dari komunitas bahasa itu sendiri. Boleh jadi penciptaan lingkungan dimaksud mengalami kejenuhan. Oleh sebab itu, diperlukan adanya program keberlanjutan yang bersifat variatif dan kreatif dalam penciptaan suasana yang kondusif.

Kelima, prinsip pemberdayagunaan teknologi dan multimedia. ${ }^{48}$

e. Tujuan Penciptaan Lingkungan Bahasa Arab

Tujuan penciptaan lingkungan berbahasa $\mathrm{Arab}^{49}$ tidak lain adalah :

1. Untuk membiasakan dan membisakan civitas akademika dalam memanfaatkan bahasa Arab secara komunikatif, melalui praktek percakapan, diskusi, seminar, ceramah, dan berekspresi dalam tulisan.

2. Memberikan penguatan pemerolehan bahasa Arab yang sudah dipelajari dalam kelas, sehingga pelajar lebih memiliki kesempatan untuk mempraktekan bahasa Arab.

3. Menumbuhkan kreativitas dan aktifitas berbahasa Arab yang terpadu antara teori dan praktek dalam suasana informal yang santai dan menyenangkan.

f. Strategi Pengembangan Lingkungan Barbahasa Arab

Lingkungan berbahasa Arab yang ideal adalah lingkungan yang memungkinkan pembelajar merasa enjoy, fun, dan happy dalam belajar bahasa Arab, sehingga kesan dan " citra negatif” selama ini bahwa “

48 Sejalan dengan hal ini Hamalik mengemukakan bahwa pemakaian media pembelalajaran dalam proses belajar mengajar dapat membangkitkan keinginan dan minat baru, membangkitkan motivasi dan rangsangan kegiatan belajar, dan bahkan membawa pengaruh-pengaruh psikologis terhadap siswa. Lihat Azhar Arsyad, Media Pembelajaran (Jakarta: PT Rajagrafindo Persada, 2002), 15

${ }^{49}$ Muhbib Abdul Wahab, Epistimologi dan Metodologi Pembelajaran Bahasa Arab, 294 
bahasa Arab itu sulit dipelajari" dapat dieleminasi. Oleh karena itu diperlukan strategi dalam mengembangkan lingkungan berbahasa Arab, adapun strategi tersebut. Strategi awal yang perlu diambil dalam rangka mengembangkan lingkungan pendidikan berbahasa Arab adalah sebagai berikut: ${ }^{50}$ Arab.

Pertama, perumusan visi, misi, dan orientasi pembelajaran bahasa

Kedua, komitmen kuat dari tenaga pendidikan bahasa Arab dan pimpinan untuk melakukan perubahan lingkungan. Penciptaan lingkungan bahasa Arab mustahil dilakukan oleh beberapa orang saja. Semua pihak harus mempunyai visi, misi, komitmen, dan kepedulian yang sama dalam mengembangkan sistem pembelajaran bahasa Arab, sehingga proses penciptaan lingkungan berbahasa Arab menjadi program bersama yang menuntut upaya kolektif dan kreatif dalam realisasinya.

Ketiga, peninjauan kurikulum bahasa Arab secara menyeluruh, dengan maksud agar pembelajaran bahasa Arab bisa diintensifkan.

Keempat, perlu ada kebijakan dari pimpinan ${ }^{51}$ berupa penetapan hari khusus, misalnya jum'at sebagai hari wajib berbahasa Arab.

Kelima, berbagai kegiatan yang bernuansa kebahasa Araban seperti : diskusi, ceramah ( dengan mengundang native speaker misanya), seminar dalam bahasa Arab, penerbitan majalah dinding, jurnal bahasa Arab, perlu digalakkan, sehingga komunitas yang ada di dalamnya terbiasa mendengar dan pada gilirannya guru dapat lebih meningkatkan porsi penggunaan bahasa Arab sebagai bahasa belajar mengajar di dalam kelas maupun di luar kelas.

Keenam, lomba-lomba yang bernuansa Arab perlu di program secara berkala, seperti : lomba pidato, cerdas cermat, karya tulis, drama, komunikata Arab, debat, dan sebagainya. Sehingga komunitas yang ada di dalamnya lebih dapat meningkatkan kemampuan dan kemampuannya dalam berbahasa Arab.

Ketujuh, penyediaan sarana dan media bahasa Arab yang lebih memadai. Sarana perpustakaan juga perlu dilengkapi dengan koran-

\footnotetext{
${ }^{50}$ Muhbib Abdul Wahab, Epistimologi dan Metodologi Pembelajaran Bahasa Arab, 303-307

51 Pemimpin yang menentukan ke mana arah suatu organisasi baik kea rah tujuan internal maupun arah tujuan eksternal. Pemimpin pula yang menyelaraskan asset dan keterampilan organisasi dengan kesempatan dan risiko yang diharapkan oleh lingkungan. Lihat Jamal Lulail Yunus, Leadership Model (Malang: UIN Malang Press, 2009), 3
} 
koran, majalah-majalah, disamping buku-buku dan kamus-kamus yang berbahasa Arab.

Kedelapan, konsep asrama yang lebih dioptimalkan fungsinya dan nilai strategisnya dalam penciptaan lingkungan berbahasa Arab.

Kesembilan, peningkatan kerjasama, baik internal maupun eksternal dengan lembaga-lembaga terkait. Kerja sama semacam ini menjadi sangat penting, terutama karena kita sekarang hidup di era globalisasi yang mengharuskan kita dapat bergaul dengan bangsa-bangsa di dunia, dan salah satu kuncinya adalah menguasai bahasa asing, termasuk bahasa Arab.

Kesepuluh, perlu mentradisikan semacam reward ${ }^{52}$ kepada pembelajar yang memiliki potensi unggul dalam berbahasa Arab, sehingga mereka termotivasi untuk terus meningkatkan kemampuan mereka dalam berbahasa Arab.

g. Membangun Lingkungan Yang Membentuk Kemampuan Lisan

Pengembangan dari setiap maharah itu tidak bisa lepas dari pada latihan-latihan (tadribat) baik secara lisan maupun tulisan yang juga melibatkan kosa kata. Yang jelas dalam pengembangan maharah alkalam lebih ditekankan pada aktifitas tadribad lisan.

Diantara cara untuk mengembangkan maharal al-kalam bagi anak didik yang sudah mulai mampu berbicara dalam sebuah lingkungan khusus adalah dengan membiasakan berdiskusi dengan bahasa Arab secara terprogram, berpidato dengan bahasa Arab, atau kuliah pendek seperti kultum dan drama (masrokhiyah). Lingkungan akan menjadikan kita terbiasa menggunakan bahasa secara terus menerus untuk menyampaikan maksud dan tujuan dalam hati kita. ${ }^{53}$

Untuk dapat mencapai target-target ini maka aktfitas pembelajaran bahasa Arab yang terpenting adalah bagaimana menciptakan siswa itu dapat terlibat dalam komunikasi dan berbicara, karena sebagaimana belajar membaca dengan banyak membaca, maka belajar berbicara juga dengan banyak berbicara.

\section{Penutup}

\footnotetext{
52 Pemberian hadiah atau penghargaan terhadap prilaku belajar seseorang (extrinsic reward) banyak terbukti telah memberikan pengaruh yang penting terhadap motivasi belajar seseorang. Berdasarkan fakta ini pula banyak guru, dan dalam sistem pendidikan pada umumnya, mengonfrontasi hadiah dengan hukuman sebagai cara untuk memotivasi siswa dalam belajar. Lihat Esa Nur Wahyuni, Motivasi Dalam Pembelajaran, 6 ${ }^{53}$ Wa Mun, Metodologi Pembelajaran Bahasa Arab Teori Dan Aplikasi, 60
} 
Lingkungan bahasa adalah segala hal yang didengar dan dilihat oleh pembelajar terkait dengan bahasa kedua yang sedang dipelajari. Begitu pentingnya faktor lingkungan bahasa dalam keberhasilan pembelajaran bahasa khususnya dalam meningkatkan kemampuan berbicara. Maka dari itu, upaya penciptaan lingkungan bahasa menjadi tanggungjawab semua pihak pada lembaga pendidikan itu. Dengan demikian, semua pihak akan merasakan urgensi penciptaan lingkungan bahasa dan mendukung dengan sepenuh hati seluruh program yang terkait dengan penciptaan lingkungan bahasa. 


\section{Daftar Pustaka}

Chaer, Abdul dan Leoni Agustina. Sosiolinguitik Perkenalan Awal. Jakarta: PT Rineka Cipta, 2004.

Chaer, Abdul. Psikososiolinguistik Kajian Teoritik. Jakarta: PT Rineka Cipta, 2009.

Hamid, M. Abdul dkk. Pembelajaran Bahasa Arab; Pendekatan, Metode, Strategi, Materi, dan Media. Yogyakarta: Sukses Offset, 2008.

Hamid, M. Abdul. Mengukur kemampuan Bahasa Arab Untuk. Studi Islam. Malang: UIN Maliki Press, 2010.

Izzan, Ahmad. Metodologi Pembelajaran Babasa Arab. Bandung: Humaniora, 2009.

Kholid, Idham. Penelitian mandiri tentang pengarub lingkungan bahasa terhadap hasil pembelajaran bahasa Inggris pada MAN Model Bandar Lampung. diterbitkan online, Bandar Lampung: Institut Agama Islam Negeri Raden Intan, 2006.

Machmudah, Umi dan Abdul Wahab Rosyidi. Active Learning Dalam Pembelajaran Bahasa Arab. Malang: UIN Maliki Press, 2008.

Mujib, Fathul. Rekontruksi Pendidikan Bahasa Arab. Yogyakarta: PT Bintang Pustaka Abadi, 2010.

Muna, Wa. Metodologi Pembelajaran Bahasa Arab Teori Dan Aplikasi. Yogyakarta: Sukses Offset, 2011.

Mustofa, Saiful. Strategi Pembelajaran Inovatif. Malang: UIN Maliki Press, 2011.

Rosyidi, Abdul Wahab. Media Pembelajaran Bahasa Arab. Malang: UIN Malang Press, 2009.

Rosyidi, Abdul. Wahab dan Rosyidi Mamlu'atun Ni'mah. Memahami Konsep Dasar Pembelajaran Bahasa Arab. Malang: UIN Maliki Press, 2012.

Wahab, Muhbib Abdul. Epistimologi dan Metodologi Pembelajaran Bahasa Arab. Jakarta: UIN Jakarta Press, 2008.

Wahyuni, Esa Nur. Motivasi Dalam Pembelajaran. Malang: UIN Malang Press, 2009.

Wassid, Iskandar dan Dadang Sunendar. Strategi Pembelajaran Bahasa. Bandung: PT Remaja Rosdakarya Offset, 2009.

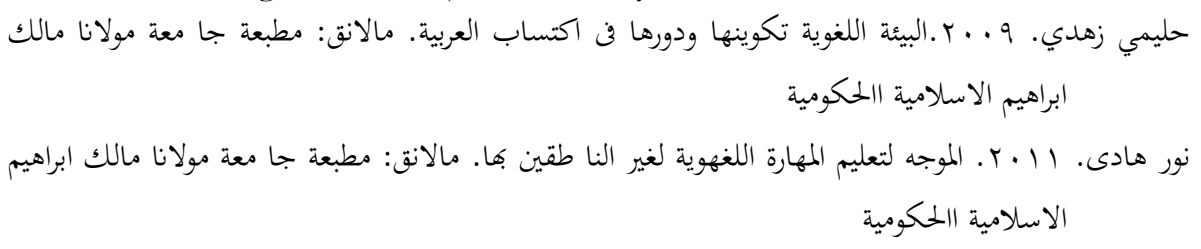

141 Baiq Tuhfatul Unsi - Kemahiran Berbicara Bahasa Arab 